\title{
WORLD SPATIAL FEATURES OF DOING BUSINESS
}

\author{
Olga Tkachuk', Valentyna Khachatryan²
}

\begin{abstract}
This article determines that in today's conditions of doing business, the increase of profits is one of the main reasons for the emergence of social challenges, such as social insecurity, low level of solvency of most people, lack of high moral values. Today, the most important is building business relations, primarily, on the basis of implementation of moral and ethical principles that can contribute to the general welfare. So, the subject of research is the ways to ensure optimal conditions for growth of small and medium business with the using of world experience, as well as studying the main directions that realized by successful states for support of entrepreneurship. Methodology. The conducted research shows that the level of corruption in Ukraine, imperfect legislation, and volatile tax system with significant load negatively affect the activities of small and medium-sized businesses. However, availability of economic stability, favourable tax and lending rates, tangible government support testify that there are optimal terms for doing business in such countries as the USA and member states of the EU. Content analysis is carried out on materials of works of foreign and domestic scientists using Ukrainian official and statistic data provided by experts. In the process of preparing the article, the general scientific methods of research are used: logical analysis, observation, formalization, synthesis, abstraction. The goal of the study is to analyse the main peculiarities of start-up and doing of entrepreneurial activity in the format of individual world countries, which give an optimal environment and favourable conditions of development of small and medium business and are interested in attracting foreign entrepreneurs for building their business, as well as identify basic mechanisms used by governments of these countries to support equilibrium in the spatial market. Conclusions. So, the analysis of main features of launch and implementation of business in the cut of individual world countries showed that the essential task of the present is an introduction of moral laws and ethical principles into business space, which is able to ensure the optimal development of social relations. Also, it is determined that start of any business for an entrepreneur is connected, first of all, with the choice of the most attractive kind of activity, taking into account which goods and services are currently in demand by consumers. In addition, it has been discovered that today the best territory in the world for conducting business is the USA with its powerful domestic market, honest legislation, and state support. For Ukrainians, it is appropriate to create a business in neighbouring states members of the $\mathrm{EU}$, whose governments actively promote the optimal terms for foreign entrepreneurs to open own business, separately, in Poland, Slovakia, the Czech Republic. At the same time, it has been investigated that corruption is the main reason that hampers the development of civilized business relations in Ukraine. Imperfect legislation and unstable tax system with a significant load negatively affect the activities of small and medium companies, complicating conditions for obtaining loans, increasing risks, primarily as a result of the growth of inflation. Thus, significant government support, especially loyal attitude towards small and medium businesses under the simple conditions of attracting investors, provides opportunities for effective business development in the EU.
\end{abstract}

Key words: business, capital, entrepreneurship, social responsibility, business culture, right, tax allowance.

JEL Classification: M14, M21, M38

\footnotetext{
Corresponding author:

${ }^{1}$ Vinnytsia Institute of Trade and Economics of

Kyiv National University of Trade and Economics, Ukraine.

E-mail: doc.olga@ukr.net

ORCID: http://orcid.org/0000-0002-1277-8202

${ }^{2}$ Vinnytsia Institute of Trade and Economics of

Kyiv National University of Trade and Economics, Ukraine.

E-mail: khachatryan9191@ukr.net

ORCID: http://orcid.org/0000-0002-9532-0116
} 


\section{Introduction}

The groundwork of doing business in the world practice remain unchanged and based on the honest performance of contractual obligations, timeliness, and the formation of high quality in receipt of results, proceeding on the fact that the main orient is the achievement of socio-economic efficiency. Of course, unprofitable entrepreneurial activity is doomed to failure - it is leaving from the market, closing biz or diversifying.

Starting up any business for an entrepreneur is beginning from an understanding of which direction is most the attractive for him - what is the most interesting thing to do and what is under force, as well as what goods and services today the demand of consumer directs. After determining the scope of activity, the next stage is directly organization of own business - the preparation of the business plan. Going on the thorny path of entrepreneurship, a person repeatedly faces many complex issues and is experiencing a lot of ups and downs, regularly turning to the business plan, adjusting it according to changes taking place in the internal and external environment of the company (Poteet, 1994).

An important toolkit of enterprise management is planning of profits. Consequently, the business strategy is oriented towards profitability, so the plan is fundamental. As a whole, total profit of company should be equal to the amount that is able to provide the required level of return on investment and decent remuneration of the owner's labour, taking into account staff salaries and tax liabilities payments.

\section{Literature review, goal and tasks of the research}

The great amount of works of well-known foreign scientists, particularly David J. Rachman (1995), Michael H. Mescon (1995), Courtland L. Bovee (1995), John V. Thill (1995), G. Howard Poteet (1994), Joan A. Johansen (1994), Antonio M. Olmi (1994), John M. Murphy (1994), and others is devoted to the latest theoretical and applied research of the ways of organization of own biz, its functions, social responsibility, legal and psychological environment, which promotes development of entrepreneurship. As well, they are considering the basics of doing business, its organizational structure, ethical norms and practices of management, the sequence of actions during the purchase or sale of the company, the choice of the legal status of the organization and management of cash flows.

The aim of research of many Ukrainian economists is studying such important issues as: main innovative approaches of organization of international business and specifics of the conceptual views on the working and implementation of business strategies of transnational companies - V.P. Onishchenko (2015); basic provisions of business ethics, ethical problems of business relations in the field of entrepreneurship and management -
O. Lesko, M. Pryshchak, O. Zaliubivska, G. Ruzakova (2011); challenges, related to starting up and doing business with foreign partners taking into account their ethnic characteristics - I. Dumanska (2014); the main directions of improvement of innovation and investment activity in the modern transformational conditions of development - S. Usherenko (2014); main tendencies of functioning and improvement of domestic business in modern terms - I. Prychepa (2017).

The following directions, as we think, require further consideration: prospects of conducting Ukrainian business abroad; the choice of more favourable conditions for starting own affair in other countries; an overview of the opportunities that individual states provide to foreign nationals for the opening of business.

The goal of the research is to analyse the main peculiarities of start-up and doing business in the format of individual world countries, which give an optimal environment and favourable conditions of development of small and medium business and are interested in attracting foreign entrepreneurs for building their business, as well as identify basic mechanisms used by governments of these countries to support equilibrium in the spatial market.

The main tasks of our study is to find the successful terms and opportunities for doing Ukrainian business in other states, confirm the importance of forming modern relationship only on the basis of application of moral values and ethical principles in presence of social responsibility of entrepreneurs, and also to clarify head challenges that hinder the development of domestic business that, in turn, directs Ukrainians for doing entrepreneurial affairs abroad.

\section{The principles of forming a moral and socially responsible business}

In modern conditions, the desire to accumulate capital is one of the main reasons for the emergence of social problems, in particular, such as social insecurity and low level of material possibilities of most people, lack of high intellectual and moral development of the population. An essential task of the present is the introduction into the public economic space of moral laws that are able to provide the optimal distribution of national wealth. It is known that almost half of the world's achievements (46\%) are owned by $1 \%$ of the population, which has wealth 65 times bigger, as of capital of rest of citizens (REUTERS).

Unfortunately, the economy in Ukraine in comparison with the countries of European Union is characterized by more significant social imbalances, since in the $90 \mathrm{~s}$ of the 20th century, a new social structure of domestic society with a significant polarization on the poor and extremely wealthy has begun forming (Cherenko, Makarova, Libanova, 2012). At a new stage in the development of the return to lost landmarks, when the 
economic theory was considered in close connection with moral values, the latter serve as a fundamental basis for eliminating or smoothing inequalities. Moral economy is a price type of housekeeping of internally rich people, living in society according to spiritual laws (Kryuchkova, 2011).

Traditionally, morality is consistent with Christian values. At the same time, main principles shaping freedom and responsibility of personality, united and fair society, an independent competitive state are the following (Institute of Economic Strategies, 2011):

1. The priority of the spiritual over the material things; fidelity to ethical laws and moral norms is the basis of national self-determination.

2. The priority of state strategic and public interest over private, conjuncture one.

3. Leading socio-political role of the state-embodiment of national independence.

4. Confirmation of rights and private dignity of a person in close connection with his moral responsibility to others.

5. The development of civil society is a guarantee of a personality's growth and the establishment of social justice.

Any freedom and independence imply a responsibility for personal choice, realized in own, freely accepted decision. At the same time, there is a subsequent dependence - the more freedom, the greater the responsibility.

For building the moral and socially responsible business as a condition for the development and prosperity of a society, such principles can be used (Institute of Economic Strategies, 2011):

1. Except for material goods, it is necessary to take into account the spiritual meaning of life, worrying about others, social welfare.

2. Accumulation of capital is not an end in itself but contributes to the formation of decent standards of living for every human and all community. First of all, it is about the donation of a certain part of the incomes for social needs.

3. The culture of business relations, fulfilment of obligations help to become better for man and business. Non-execution of agreements reduces the reputation of an entrepreneur, and as a consequence - the image of the country in general.

4. A person needs time for spiritual life, relaxation, creative expression.

5. The state, society, business should promote the worthy existence of those who work, including the incapacitated population of the country.

6. Work should be realized in safe terms for the employee, as well as in the absence of illegal methods of doing affair (violence, threats).

7. Political and economic powers should be distributed. Participation of business in policy can be only transparent and open.
8. The inability of entrepreneur to ignore moral laws by appropriating someone else's property, establishing low wages, misleading partners, consumers.

9. In a competitive relationship, one should not use human weaknesses and instincts. The competition is worthy and morally justified when it does not ruin business ties.

10. It is necessary to respect any property and the right of other people to dispose of their capital; encroaching on someone else's things is immoral.

So, the human-oriented policy of a company can be a successful economic strategy. About it evidences the experience of leading European countries, in which the level of development of social responsibility is significantly higher than in Ukraine. Realizing social tasks, the enterprise "makes the world better," acquires a good image in state institutions, consumers of products, partners, and personnel. According to FleishmanHillard in the EU, $87 \%$ of employees of European companies feel highly involving during work at a socially responsible organization (Dokuka).

Social responsibility is a part of the business culture and ethics of leading companies in the world, providing a number of benefits at the state, regional and corporate levels. Among them - an improvement of reputation in business space, between consumers, strengthening of competitive positions, the growth of trust and as a result - an improvement of financial indicators of activity, the formation of a safe natural environment, increase of professionalism of personnel and its cultural level. The latter promotes the development of economic systems, expansion of social stability and growth of living standards on the basis of the embodiment of spiritual and moral principles in society.

The category of "social responsibility" in Ukraine and abroad is perceived differently. In the understanding of foreigners, a socially responsible company adheres to public social laws, cares about the material wellbeing of its workers, and optimally utilizes resources, motivating to innovative development. Ukrainian businessmen see own role more narrowly, limited to the payment of tax obligations, the implementation of state legislative requirements and charity (Kotler, Lee, 2005).

In general, entrepreneurs in the world are the same people as everyone else: they show their responsibility to society and the environment, adopting ethical rules defining the values and principles that need to be used for decision-making (Rachman, Mescon, Bovee, Thill, 1995).

Many successful companies are trying to encourage their workers on the example of taking their own participation in public life. They are engaged in charity, sacrificing significant funds for social needs and environmental protection. In general, the corporation consists of separate individuals, who approve decisions based on private moral benchmarks. In the case that every person in the organization acts in accordance with ethical standards, the entire company behaves 
accordingly - a total favourable internal microclimate is formed. The key is each worker must have a good understanding of the consequences of own actions and make the right choice. But it is often impossible to divide the situation into "white and black." In this case, there are three advisable philosophical principles that allow us to determine the correctness of actions: utilitarianism, respect for human rights and justice.

In accordance with the concept of utilitarianism, the right decision is characterized by the fact it can give maximum benefit to most people. The value of this approach depends on the ability of an individual to predict and analyse the consequences of their decisions, requiring such one that will serve the majority.

The observance of human rights is based on faith and the duty to protect the rights of others and to reject any decision that is in the position to violate that. Management respects the right of the individual on the secret or open detection of thoughts and it does not motivate workers till actions against their interests, religious or ethical looks.

Principles of justice are in that all people demandidentical relation, and the established social rules should be carried out steadily by them. Those who do the harm others have to be liable, compensating for the losses. So, a fair decision is honest, impartial and reasonable, consistent with ethical rules that can be applied in a particular situation (Rachman, Mescon, Bovee, Thill, 1995).

In the 1960s of the 20th century, the level of responsibility of businessmen to buyers has increased, the respect to their needs has grown. It was observed more attentive perception of consumer rights, in particular: to security, to obtaining reliable information, to choice and presentation of claims (Table 1).

The right to safety means: the existence of a list of certain standards for produced goods; the necessity to comply with them by manufacturers and entrepreneurs that is controlled by the government. Along with the rigorous actions on the part of the state, there are the following incentives that encourage of manufacturers to abidance of products safety norms: the criminal responsibility, the reduction of volumes sales in case violation of requirements (for example, loss of reputation).

The right to receive information implies the existence on the label of truthful pointers of the risks associated with the use of this product. Regardless of whether it is useful or harmful, consumers have the right to obtain reliable information about the composition, cost, and rules of application. Over time, governments have developed many laws and regulations, the purpose of which is the prohibition in providing incorrect data about goods by manufacturers.

Business responds excellently to the right to choose: the amount of various goods available to the consumer today is amazing. The question is only in the limits of the decision, on what products there is a big choice harmful (cigarettes, alcohol), such as air corn or dubious rock music, etc. Also, or is it necessary to prohibit certain types of advertising, such as targeted at children.

The right of consumers to make claims finds consent and understanding in most successful companies. They actively work with reviews of clients (that help to correct errors) and make good decisions about the release of new products and services, based on information received from consumers (Rachman, Mescon, Bovee, Thill, 1995).

As for the interaction of businessmen with wage earners, one of the varieties of incentive reward is a premium - payment more than a regular salary, in particular, till the holiday, as encouragement, for accelerating the turnover of commodity stocks during the year or achieving the goals of company and commissions (percentages) based on sales volume (Rachman, Mescon, Bovee, Thill, 1995).

\section{The best territory for doing business today and the main challenges of Ukrainian business}

And so, we think, the best territory for doing business today is the USA. It is a great option for those who want to build an honest affair. The powerful inside market, low level of corruption, government support and promotion to development of small business, positive attitude of people for entrepreneurship allow working with pleasure: there is a real possibility to invest own money usefully and do profitable business. Want to note that the lowest in the world taxes interest rates are in the USA, and they are absent in general in Wyoming and Nevada, except annual re-registration fee. Owner of business - foreigner has a right to receive the domicile in the country and in 5 years - to citizenship.

The features of doing business in the USA are the following (2016):

Table 1

Consumer rights in business relationships controlled by the government

\begin{tabular}{|l|l|}
\hline \multicolumn{1}{|c|}{ Consumer rights } & \multicolumn{1}{c|}{ Essence } \\
\hline Right to security & Availability of a list of certain product standards that producers and entrepreneurs need to follow \\
\hline Right to reliable information & Presence of reliable information about the composition, cost, and rules of application of products \\
\hline Right to choice & Availability of a variety of goods and services available to the consumer \\
\hline Right to presentation of claims & $\begin{array}{l}\text { Customer reviews that help the manufacturer or the entrepreneur to correct mistakes and make better } \\
\text { decisions about the products and services offered }\end{array}$ \\
\hline
\end{tabular}

Source: (Rachman, Mescon, Bovee, Thill, 1995) 
1) for open business, it is necessary to start all from scratch - experience will not be needed. It concerns the basics of busy converse, building a relationship with partners, the study of special English literature and research of communication skills during interaction with different organizations, as well as monitoring of experience of other companies in terms of tough competition;

2) it is possible to work only in civilized methods with the help of the realization of different marketing technologies and by way of creation of trust relationship with clients. Friendly or family ties in the administration are not transferred to working relations, the conduct of tender policy solves all issues;

3) compliance with the rules of etiquette is mandatory. Successful are those companies that have good service and careful attitude towards buyers. It is advisable for the business owner to communicate independently with the clients, take up of correspondence, meetings, actively engaging in business processes.

In the USA, it is customary to ask for yourself: a job promotion, participation in the interesting project with the application of the effort and justification of the proposal.

Also, the using of outsourcing, in particular, in accounting, legal direction, technical support, and staff remuneration is a good decision. It is the reliable, relevant, relatively inexpensive way that demonstrates the conduct of transparent business. It should be recalled that outsourcing is a system of operations aimed at transferring certain processes and functions from one company to another one - this is essentially the use of other resources.

Corruption is the main reason that hinders the development of civilized business relations in Ukraine. By the level of the latter in 2017, the state was in the first place among 41 of the European countries (Doing business in Ukraine and the EU). Small and medium companies suffer the most - bribery obstructs to take profits. There is also a situation of extreme politicization of business: most government officials are owners or beneficiaries of private enterprises, they defend the interests of big business.
As we know, the beneficial owner is a person or several persons who directly (indirectly) owns the company or have a significant influence on making important decisions. This is not always defined in the constitutive provisions of legal entity, but in fact, it is the owner of all assets and receives incomes from organizational activities. The personality of the beneficiary is often not disclosed, it is hidden behind a number of fictitious firms or directors. The latter may be used for money laundering. With the legitimate purpose, such owners are kept secret for tax planning.

Consequently, an ordinary citizen has essential problems with reproducing transparent business relations: some companies have privileges and incentives, despite significant legislative violations, others - operate in conditions of lengthy audits in the absence of serious legal mistakes.

Imperfect legislation and an unstable tax system with a high level of load also negatively effect on the entrepreneurial activity of small and medium companies. Now Ukrainians have less own funds to open a business, at the same time, the conditions for obtaining loans are complicated, and risks are rising, first of all, as a result of an increase in inflation. The distribution of the main business problems in Ukraine from the point of view of entrepreneurs and society is given in Table 2.

So, an increasing number of domestic businessmen are interested in opening own affair in the EU. Economic stability, favourable tax and lending rates, and tangible government support cause the desire in Ukrainians to do business right there. There is a particularly loyal attitude towards small and medium businesses in the EU, with simple conditions of attracting investors. Anticorruption legislation and national mentality of Europeans provide for transparent entrepreneurship conduct.

The governments of the EU member-states offer entrepreneurs tax rates, much lower than in Ukraine. At the same time, a stable EU economy ensures the ability of banks to provide low-interest rates, creating tangible benefits for businessmen.

Table 2

The positioning of modern challenges in Ukrainian business

\begin{tabular}{|l|l|l|c|}
\hline \multicolumn{2}{|c|}{ In terms of entrepreneurs } & \multicolumn{2}{c|}{ From the point of view of society } \\
\hline Currency instability & $78 \%$ & Currency instability & $78 \%$ \\
\hline Low buyers ability & $69 \%$ & Low buyers ability & $70 \%$ \\
\hline High taxes & $60 \%$ & High taxes & $75 \%$ \\
\hline The legislative vulnerability of business & $40 \%$ & The legislative vulnerability of business & $63 \%$ \\
\hline Difficulty in managing taxes & $37 \%$ & Difficulty in managing taxes & $46 \%$ \\
\hline Pressure from the controlling institutions & $30 \%$ & Pressure from the controlling institutions & $64 \%$ \\
\hline Difficulties in lending & $24 \%$ & Difficulties in lending & $34 \%$ \\
\hline Complicated customs procedures & $13 \%$ & Complicated customs procedures & $36 \%$ \\
\hline
\end{tabular}

Source: Melnyk, 2018 


\section{Investigation of doing business conditions in some European countries with the identification of the possibilities for opening Ukrainian business there}

So, in the list of Doing Business, Poland ranks the 45th position among world countries (Association of Ukrainian Business in Poland). Establishing company there, an entrepreneur automatically gets access to European lending with minimum rates. The Government is pleased to support foreign investors through tax privileges, subsidies, the creation of special economic regions, grants - depending on the type of business activity. Regarding targeted assistance from the Polish state budget or with the EU, the conditions for obtaining are the following: the presence of significant investments, the creation of vacancies for the citizens of Poland, support for the development of the field of innovative technologies.

Poland is the best place for Ukraine to open business abroad: a similar language, close cultural traditions, simplicity and a certain low cost of its launch. Also, the entrepreneur gets access to the markets of EU memberstates. The profitable business can be servicing computer equipment, creating translation agency and beauty salons or companies engaged in importexport operations with Ukrainian counterparts. In our opinion, the important feature is a lack in Poland of restrictions on the reproduction of operations in foreign currency. At the same time, companies established by non-residents can be financed from sources located abroad.

Regarding doing Ukrainian business in Slovakia, it should be noted that the country represents itself on the European market, first of all, as a tour operator that is a very attractive niche for opening own affair. Profitable can be various small companies, such as confectioneries, car-care centres or agribusiness. In the innovation sphere - there are Internet commerce, IT companies, and bioenergy. The government actively supports the latter by providing guarantees for a ransom of green electricity at fixed rates for 15 years (Business in Slovakia). By investing in a start-up business, the entrepreneur is able to count on investment stimulation and privileges, the terms of receipt of which depend on the degree of regional growth, level of unemployment and volume of investments - in compliance with the EU legislation.

In turn, the Czech Republic provides foreigners with several opportunities for entrepreneurship (How to "relocate" the Ukrainian business to the Czech Republic). First of all, these are hotel and restaurant business, excursion bureaus, souvenir shops, as well as small business - trade, leasing real estate, beauty industry, etc. The attractiveness of the country for conducting business is the fact that foreign and Czech entrepreneurs have the same rights during the registration of own affair. Also, in the process of entrepreneurship establishment in Czechia, the owner gets access to markets of the EU countries and permission to purchase real estate or land on the territory of the state with receiving a business visa for a year with the possibility of its extension.

Foreign business in the country can use tax or monetary privileges (in particular, due provision of jobs to the Czech population or financing the professional development of employees). As for the EU market, despite the fact that it is one of the most liberal in the world, it contains the tools of restricting trade for countries which are not the members of the union.

The specialties of the EU's trade ties with other countries have several common features:

1) protective mechanisms of trade relations used by the EU member countries, created on the basis of main principles of the WTO;

2) they are the groundwork for the existence of a free market and provide open competition between companies of the EU member states and producers from other countries;

3) through the effective use of safeguard mechanisms for free trade, there is a significant reduction in imports due to the strengthening of anti-dumping policy (Features of doing business in the EU).

In order to maintain the optimum trade balance and protect producers of the EU member states, some specific tools below discussed are used (Features of doing business in the EU).

Anti-dumping mechanisms. As you know, dumping is a process, within which a manufacturer from a country that is not a member of the EU sells in it goods at prices lower than market or production cost. In the conditions of illegal actions on anti-dumping legislation, the foreign producer must necessarily compensate for the caused damage. Penalties may be: fixed, varied or calculated as a percentage from the total supply volumes.

Anti-subsidy measures. The subsidy, in this case, is targeted support from non-EU countries of national producers, as a result of which the latter are able to sell products at prices lower than market or production costs. For support of the equal competitive environment, the export of such products to the EU is terminated, and its exporters/importers must pay penalties, which appear in additional import duties on these goods.

Preventive (precautionary) steps are used during rapid changes of market conjuncture in a situation where the volume of exports of certain goods to the EU increases so quickly that the member states of the association don't have time to adapt to new trading conditions. In this case, the EU in conjunction with the WTO are developing and implementing special measures to correct and stabilize the microclimate in a competitive space, etc. 


\section{Conclusions and recommendations for further research}

So, the analysis of main features of launch and implementation of business in the cut of individual world countries showed that the essential task of the present is an introduction of moral laws and ethical principles into business space, which is able to ensure the optimal development of social relations. Also, determined that start of any business for an entrepreneur is connected, first of all, with the choice of the most attractive kind of activity, taking into account which goods and services are currently in demand by consumers. It has been defined that social responsibility is a part of the business culture and ethics of leading global companies, which provides them a lot of advantages at the state, regional, and corporate levels.

In addition, it has been discovered that today the best territory in the world for conducting business is the USA - with its powerful domestic market, honest legislation, and state support. For Ukrainians, it is expedient to create a business in neighbouring states members of the EU, whose governments actively provide the optimal terms for foreign entrepreneurs during opening own business: these are Poland, Slovakia, and the Czech Republic. So, having established a company in these countries, foreign owner obtains access to the EU markets, economic stability, favourable tax and lending rates, and tangible government support cause desire in Ukrainians to do business exactly there. Also, the anti-corruption legislation and national mentality of Europeans ensure transparency of business.

At the same time, it has been investigated that corruption is the main reason that hampers the development of civilized business relations in Ukraine. There is also a situation of extreme politicization of business: most government officials are owners or beneficiaries of private companies or defending the interests of big business.

Imperfect legislation and unstable tax system with a significant load negatively affect the activities of small and medium companies, complicating conditions for obtaining loans, increasing risks, primarily, as a result of the growth of inflation. Fixed, that EU governments offer entrepreneurs tax and credit rates significantly lower than in Ukraine.

It is established that following powerful tools are being used to maintain the optimum trade balance and protection of local producers in the EU: anti-dumping, anti-subsidy and preventive measures - therefore, as we see, the EU member countries take care about own spatial development and welfare of their citizens.

Thus, significant government support, especially loyal attitude towards small and medium businesses with simple terms of attracting investors, provides opportunities for effective business development in the EU. That's why it is quite justified that today Ukrainian entrepreneurs are interested in starting their own business in the EU.

\section{References:}

Asotsiatsiia ukrainskoho biznesu v Polshchi [Association of Ukrainian Business in Poland]. Retrieved from: http://ukrbizpol.org/

Biznes v Slovakii [Business in Slovakia]. Retrieved from: http://persona.pumb.ua/ua/club/digest/detail. php?CODE=biznes-v-slovakii-chto-stoit-znat-ob-osobennostyakh-mestnogo-rynka

Cherenko, L. M., Makarova, O. V., Libanova, E. M. (2012). Liudskyi rozvytok v Ukraini: transformatsiia rivnia zhyttia ta rehionalni dysproportsii [Human development in Ukraine: transformation of living standards and regional disparities]. Kyiv: Institute of Democracy and Social Implications by M. V. Ptukha of the NAS of Ukraine. (in Ukrainian)

Dokuka, S. Sotsialnaya otvetstvennost kak vysshaya stadiya kapitalizma [Social responsibility as the highest stage of capitalism]. Retrieved from: http://www.odnako.org/almanac/material/socialnaya-otvetstvennost-kak-visshayastadiya-kapitalizma/

Dumanska, I. Yu. (2014). Filosofiia vedennia biznesu inozemnymy kontrahentamy v konteksti yikh mentalnosti: porady dlia fakhivtsiv ZED [The philosophy of doing business with foreign counterparts in the context of their mentality: tips for specialists in foreign trade]. Scientific Herald of Kherson State University, 6(1), 64-68.

Institute of Economic Strategies (2011). Preobrazheniye i modernizatsiya: dukhovnyye nachala, tseli, riski i shansy [Transformation and modernization: spiritual principles, goals, risks and chances]. Moscow: Institute of Economic Strategies. (in Russian)

Kak "pereselit" ukrainskiy biznes v Chekhiyu [How to "relocate" the Ukrainian business to the Czech Republic]. Retrieved from: https://ubr.ua/business-practice/own-business/kak-pereselit-ukrainskii-biznes-v-chehiu-401279

Kotler, F., Lee, N. (2005). Korporatyvna sotsialna vidpovidalnist. Yak zrobyty yakomoha bilshe dobra dlia vashoi kompanii ta suspilstva [Corporate social responsibility. How to make as much wellfair as possible for your company and society]. Kyiv: Standart. (in Ukrainian)

Kryuchkova, O. M. (2011). Obshchestvo potrebleniya i ekonomika, osnovannaya na nravstvennom vybore [Consumer society and economy based on moral choice]. Problem analysis and public-management design, 4(4), 113-121.

Lesko, O. Y., Pryshchak, M. D., Zaliubivska O. B., Ruzakova, G. G. (2011). Etyka dilovykh vidnosyn [Ethics of business relations]. Vinnytsia: VTEU. (in Ukrainian) 
Maizhe polovyna svitovoho bahatstva nalezhyt $1 \%$ naselennia / REUTERS [Almost half of the world's wealth is owned by $1 \%$ of the population / REUTERS]. Retrieved from: http://www.unian.ua/world/874475-mayjepolovina-svitovogo-bagatstva-nalejit-1-naselennya-doslidjennya.html

Melnyk, M. I. (2018). Prostorovi formy orhanizatsii biznesu v Ukraini: tendentsii, perspektyvy ta mekhanizmy rozvytku [Spatial forms of business organization in Ukraine: trends, prospects and mechanisms of development]. Retrieved from: http://ird.gov.ua/irdp/p20180301.pdf

Onishchenko, V. P. (2015). Zovnishnia torhivlia: ekonomika, finansy, pravo [Foreign trade: economics, finance, law]. Scientific journal, 3(80), 20-31.

Osobennosti vedeniya biznesa v SShA [Features of doing business in the USA]. Retrieved from: https://gejzer.ru/ statii/osobennosti-predprinimatelstva-v-amerike.html

Osoblyvosti vedennia biznesu v YeS: importni obmezhennia, kvoty ta korysni posylannia [Features of doing business in the EU: import restrictions, quotas and useful links]. Retrieved from: http://persona.pumb.ua/ua/club/digest/ detail.php?CODE=osobennosti-vedeniya-biznesa-v-es-importnye-ogranicheniya-kvoty-i-poleznye-ssylki

Poteet, G. H., Johansen, J. A., Olmi, A. M., Murphy, J. M., etc. (1994). Entsiklopediya maloho biznesa [Starting up your own business]. Moscow: Kniga Interneshnl, Odissey. (in Russian)

Prychepa, I. V. (2017). Perspektyvy rozvytku pidpryiemnytstva v Ukraini za umov hlobalizatsii ta yevrointehratsii [Prospects for the development of entrepreneurship in Ukraine in the context of globalization and European integration]. Retrieved from: http://ir.lib.vntu.edu.ua/bitstream/handle/123456789/17096/2270. pdf? sequence=3\&isAllowed=y Rachman, D. J., Mescon, M. H., Bovee, C. L., Thill, J. V. (1995). Sovremennyy biznes [Modern business]. Moscow: Respublika. (in Russian)

Usherenko, S. V. (2014). Innovatsiino-investytsiina diialnist ukrainskykh pidpryiemstv: suchasnyi stan i priorytety aktyvizatsii [Innovative and investment activity of Ukrainian enterprises: current state and priorities of activation]. Retrieved from: http://soskin.info/userfiles/file/2014/7-8_2014/7-8_2/Usherenko.pdf

Vedennia biznesu v Ukraini ta YeS - korotko pro usi «za $\overline{\mathrm{i}} \ll$ proty» $\overline{[}$ Doing business in Ukraine and the EU briefly about all "for" and "against"]. Retrieved from: http://leopolis.news/vedennya-biznesu-v-ukrayini-ta-yeskorotko-pro-usi-za-i-proty/ 